\title{
Information on the Advanced Plant Experiment (APEX) Test Facility
}

Curtis Smith

May 2015

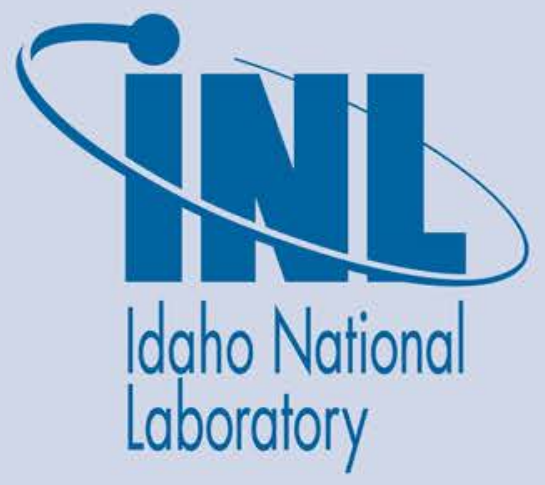

The INL is a U.S. Department of Energy National Laboratory operated by Battelle Energy Alliance 


\section{DISCLAIMER}

This information was prepared as an account of work sponsored by an agency of the U.S. Government. Neither the U.S. Government nor any agency thereof, nor any of their employees, makes any warranty, expressed or implied, or assumes any legal liability or responsibility for the accuracy, completeness, or usefulness, of any information, apparatus, product, or process disclosed, or represents that its use would not infringe privately owned rights. References herein to any specific commercial product, process, or service by trade name, trade mark, manufacturer, or otherwise, does not necessarily constitute or imply its endorsement, recommendation, or favoring by the U.S. Government or any agency thereof. The views and opinions of authors expressed herein do not 


\title{
Information on the Advanced Plant Experiment (APEX) Test Facility
}

\author{
Curtis Smith
}

May 2015

\begin{abstract}
Idaho National Laboratory Idaho Falls, Idaho 83415
\end{abstract}

http://www.inl.gov

Prepared for the U.S. Department of Energy Office of Nuclear Energy Under DOE Idaho Operations Office

Contract DE-AC07-05ID14517 


\section{Information on the Advanced Plant Experiment (APEX) Test Facility}

The purpose of this report provides information related to the design of the Oregon State University Advanced Plant Experiment (APEX) test facility. Information provided in this report have been pulled from the following information sources:

Reference 1: R. Nourgaliev and et.al, "Summary Report on NGSAC (Next-Generation Safety Analysis Code) Development and Testing," Idaho National Laboratory, 2011. Note that this is report has not been released as an external report.

Reference 2: O. Stevens, Characterization of the Advanced Plant Experiment (APEX) Passive Residual Heat Removal System Heat Exchanger, Master Thesis, June 1996.

Reference 3: J. Reyes, Jr., Q. Wu, and J. King, Jr., Scaling Assessment for the Design of the OSU APEX-1000 Test Facility, OSU-APEX-03001 (Rev. 0), May 2003.

Reference 4: J. Reyes et al, Final Report of the NRC AP600 Research Conducted at Oregon State University, NUREG/CR-6641, July 1999.

Reference 5: K. Welter et al, APEX-1000 Confirmatory Testing to Support AP1000 Design Certification (non-proprietary), NUREG-1826, August 2005. 


\section{R. Nourgaliev and et.al, "Summary Report on NGSAC (Next-Generation Safety Analysis Code) Development and Testing," Idaho National Laboratory, 2011.}

In 2011, the INL produce a technical report on attributes for a "next generation" safety analysis tool called R7. As part of this report, information was provided on the APEX facility since it was used to demonstrate the capabilities of the software. The background on this use is:

- Leveraging on a unique experimental facility APEX, at the Oregon State University

- $\quad$ APEX simulate PWR (W and CE), AP600, and AP1000

- Quarter-scale integral- effect test facility, with extensive diagnostics

- Cross-benchmarking with existing models and "legacy" STH codes

- Developing input decks compatible with R7 graphics-user interface (GUI)

- A coarse-grained OD-1D STH-grade model of APEX

- A fine-grained 3D CFD-grade model of APEX

- Analyzing past APEX experiments for their (partial) relevance to validation data needs in support of $F \& B$ scenario model calibration

General information was provided on APEX, including the following:

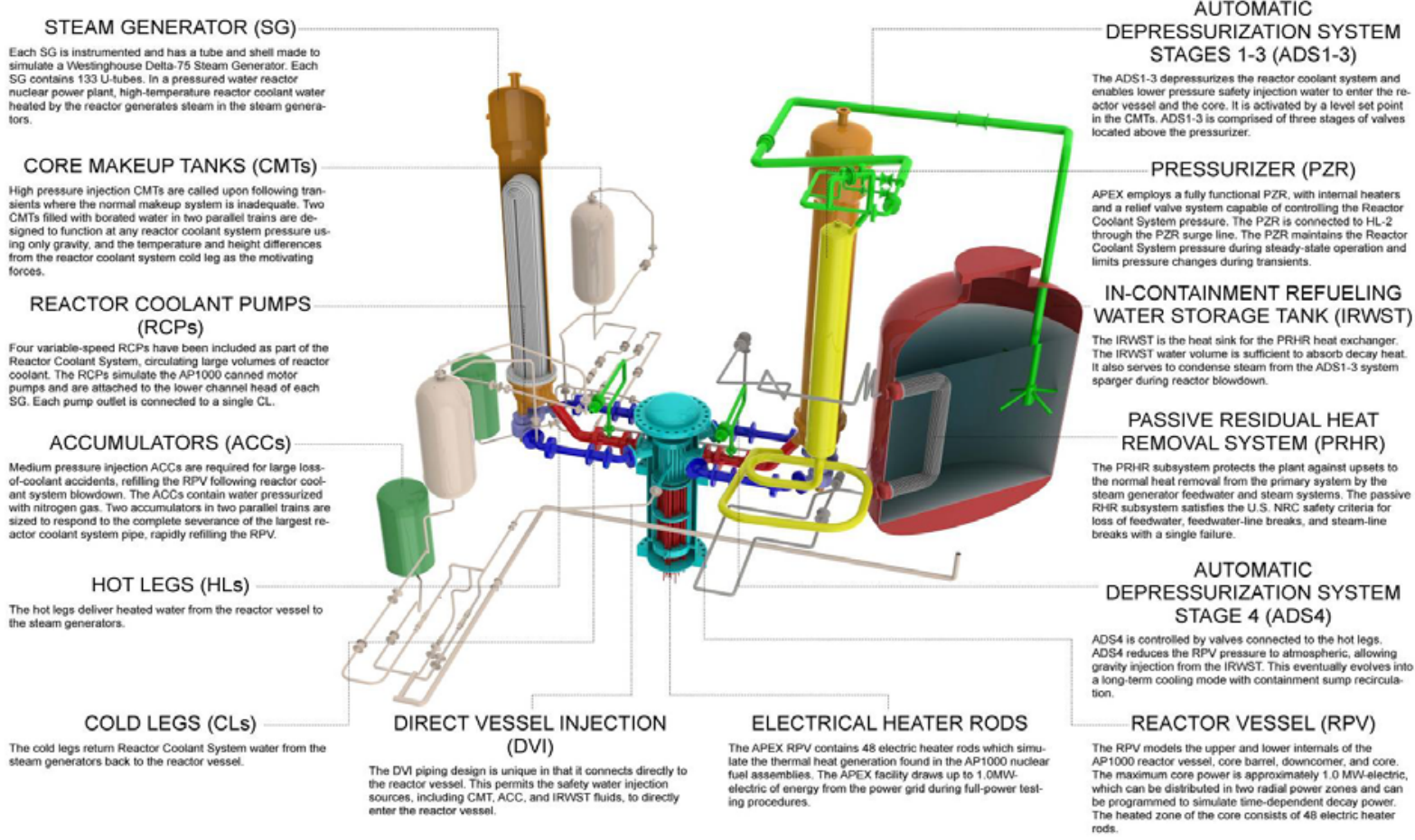


The R7 input deck (once visualized) looked like:






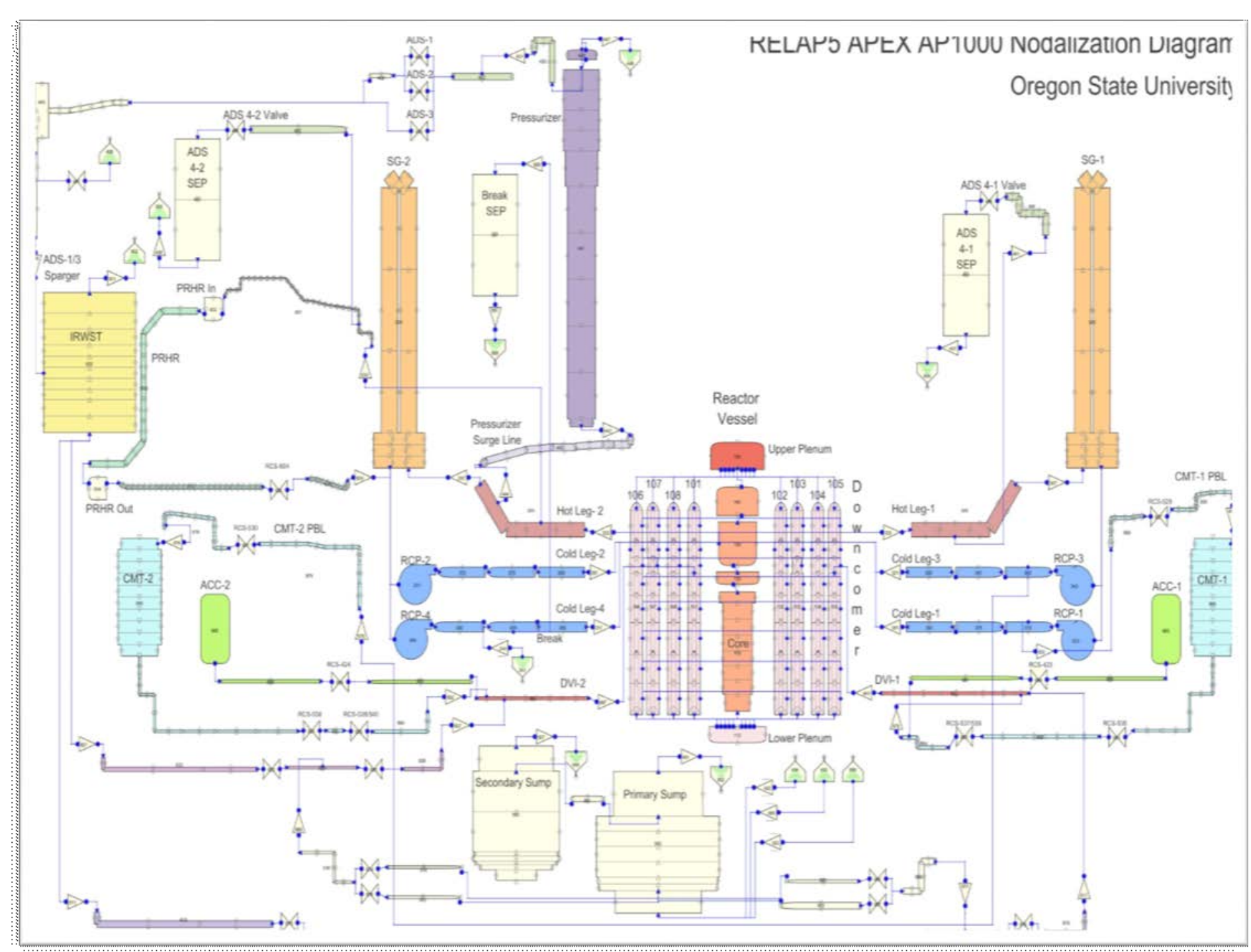

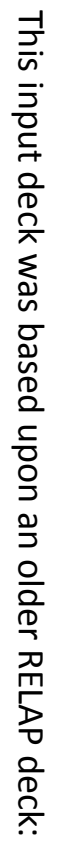




$$
1,1,
$$




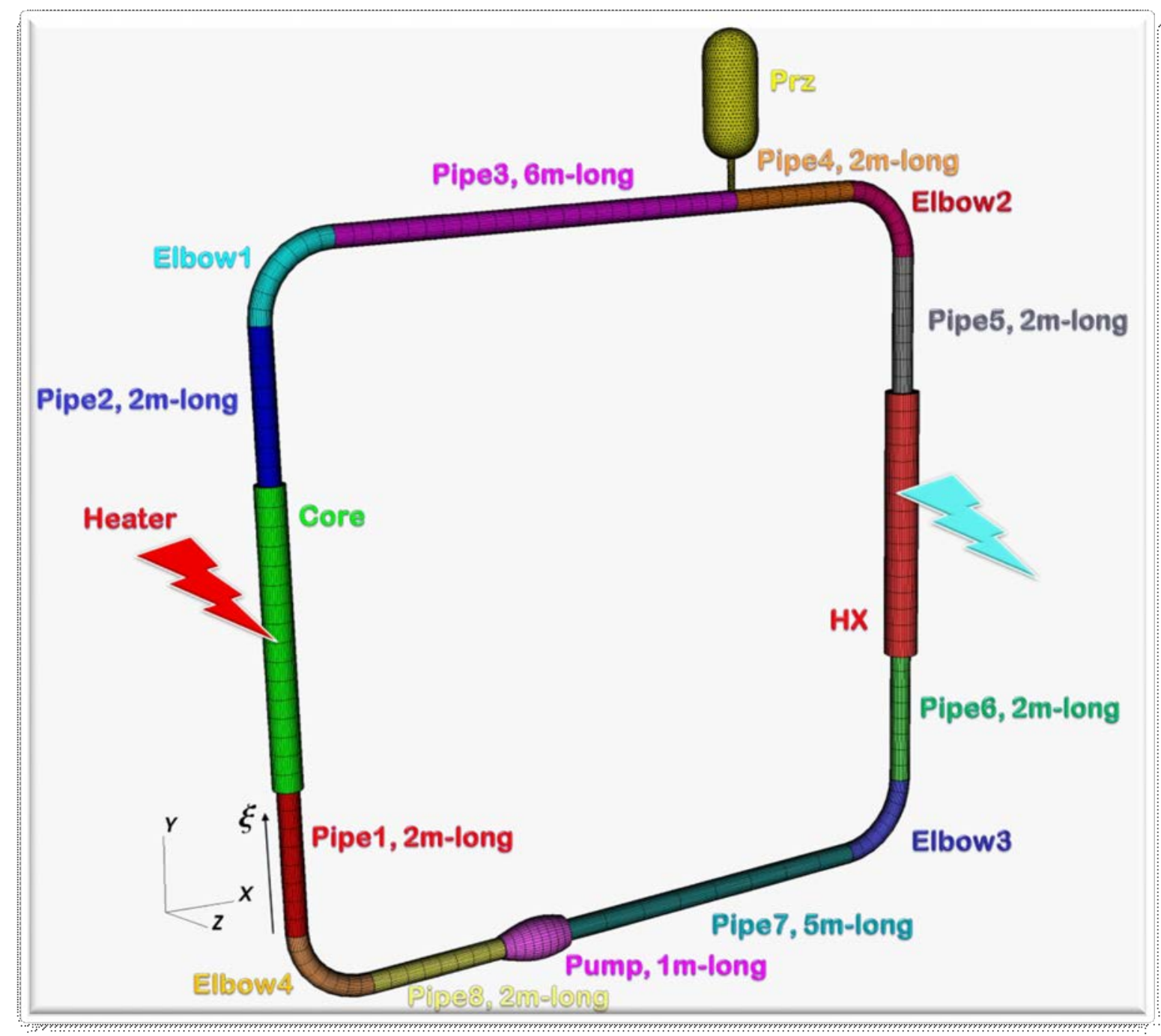

The INL also included additional details - this information was contained in the following four chapters: 


\section{Chapter 1}

\section{APEX Test Facility}

\subsection{APEX Test Facility Description}

The Advanced Plant Experiment (APEX) test facility at Oregon State University is maintained and operated by the Department of Nuclear Engineering and Radiation Health Physics. It was constructed in 1994 to perform integral system tests to simulate the important thermal hydraulic behavior of the Westinghouse AP600 reactor. The facility was then modified, through a grant from the U.S. Department of Energy, to simulate the Westinghouse AP1000 for the purpose of AP1000 plant certification through assessing system code capabilities and integral system behavior.

The test facility models a complete Westinghouse AP1000 2x4 loop containing two hot legs, 4 cold legs, 2 steam generators, pressurizer, reactor pressure vessel with an electrically heated rod bundle and upper plenum internals. It is a 1:4 length scale, 1:2 time scale, 1:192 volume scale of the prototype AP1000 and is of stainless steel construction. It completely models the passive safety systems of the AP1000 containing: 2 core makeup tanks (CMTs), 2 accumulators (ACCs), a passive residual heat removal (PRHR) heat exchanger, in-containment refueling water storage tank (IRWST), and a 4-Stage automatic depressurization system. The steady state operating conditions of the facility are with a core power at about $1 \mathrm{MW}$, steam generator shell side pressure at $2 \mathrm{MPa}$ (290 psig), and pressurizer pressure at $2.55 \mathrm{MPa}(370 \mathrm{psig}$ ). Past testing efforts utilizing APEX have include hot and cold leg SBLOCAs, MSLB, Inadvertent ADS, Double-Ended DVI Line Break, Station Blackout and Long Term Recirculation. Figure $\underline{1.1}$ show a 


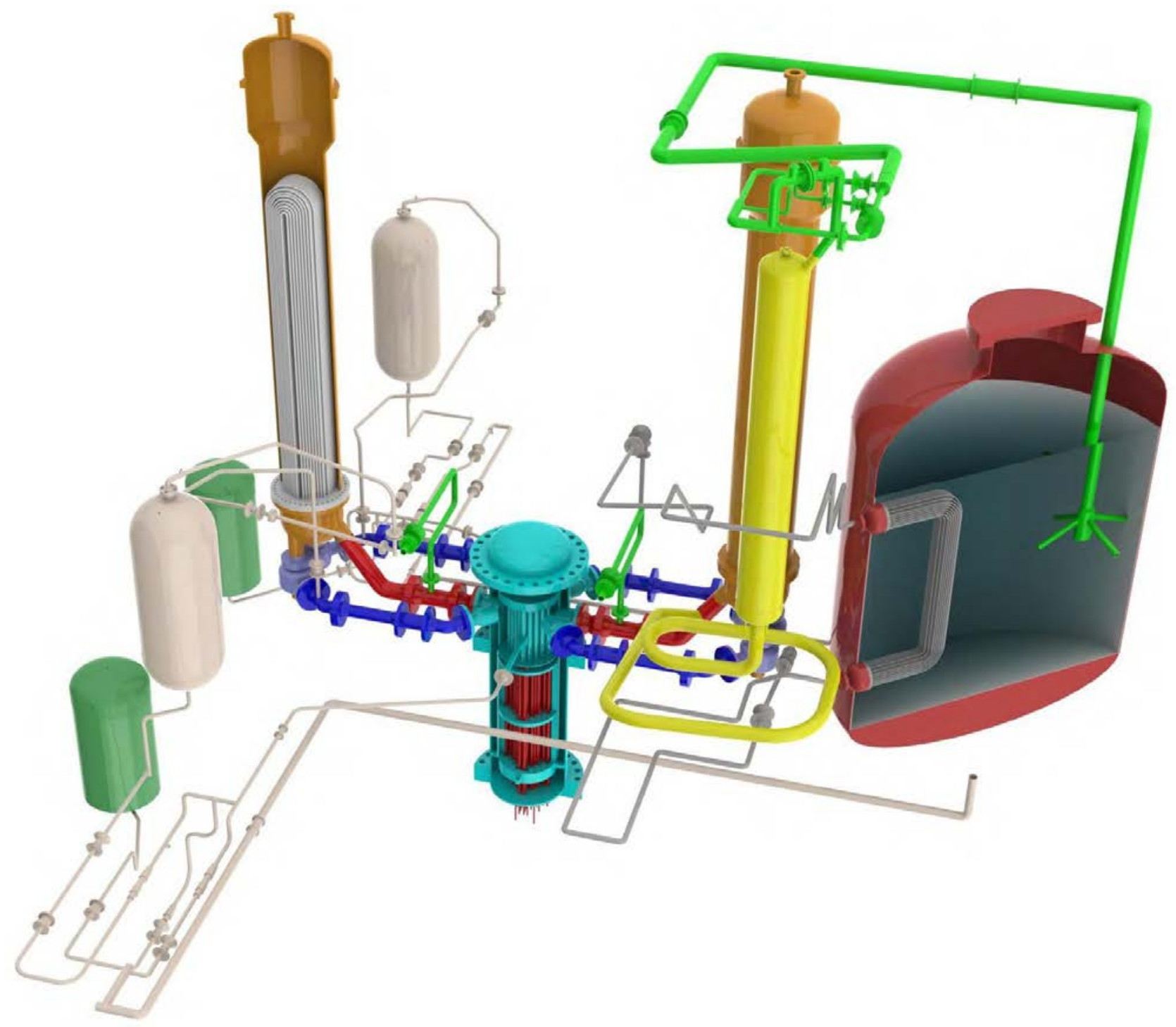

Fig. 1.1 : APEX test facility at Oregon State University. 


\section{APEX R 7 Simulation Model}

\subsection{Introduction}

The physical APEX test facility is transformed into working model within $\mathbf{R}_{\mathbf{7}}$ as shown in in Figure 2.1. The following sections work to describe the systems, sub-systems (groups), and components as they are modeled in R7 GUI. 


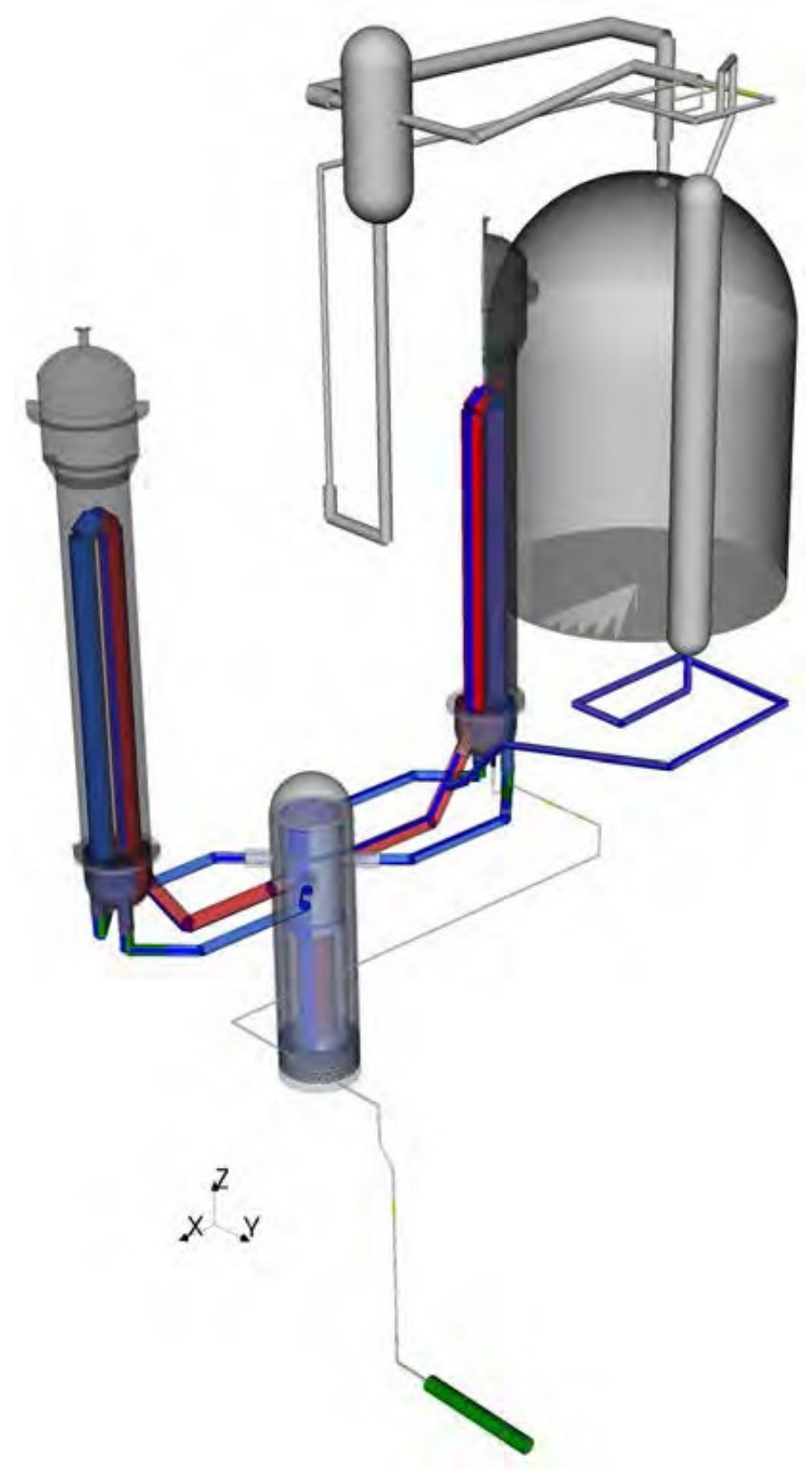

Fig. 2.1 : Model of APEX in R7 . 


\subsubsection{APEX R7 Model Groups}

The APEX test facility is broken up into groups for modeling purposes. Table 2.1 gives each group with a list of the major components of that group along with the fidelity utilized in the APEX R7 model.

Table 2.1 : APEX R7 Model Components.

\begin{tabular}{|c|c|c|c|}
\hline System & Group & Component Name & Dimension \\
\hline \multirow{21}{*}{ 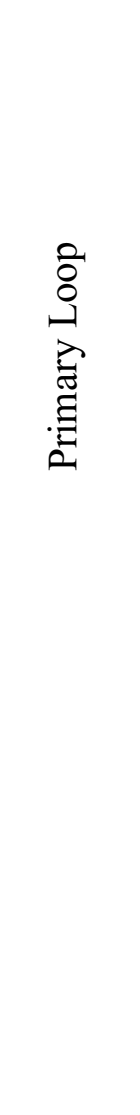 } & \multirow{5}{*}{ Reactor Pressure Vessel } & Downcomer Fluid & $1-\mathrm{D} / 3-\mathrm{D}$ \\
\hline & & Downcomer Inner Wall & $3-\mathrm{D}$ \\
\hline & & Downcomer Outer Wall & $3-\mathrm{D}$ \\
\hline & & Upper Plenum & $0-\mathrm{D}$ \\
\hline & & Lower Plenum & $0-\mathrm{D} / 3-\mathrm{D}$ \\
\hline & \multirow[t]{6}{*}{ Core } & Lower Core Plate & $1-\mathrm{D}$ \\
\hline & & Heater Rod Section & $1-\mathrm{D}$ \\
\hline & & Upper Core Plate & $1-\mathrm{D}$ \\
\hline & & Upper Internals Support Plate & $1-\mathrm{D}$ \\
\hline & & Core Upper Internals & $1-\mathrm{D}$ \\
\hline & & Upper Support Plate & $1-\mathrm{D}$ \\
\hline & \multirow[t]{8}{*}{ Cold Leg } & Cold Leg 1 & $1-\mathrm{D}$ \\
\hline & & Reactor Coolant Pump 1 & $1-\mathrm{D}$ \\
\hline & & Cold Leg 2 & $1-\mathrm{D}$ \\
\hline & & Reactor Coolant Pump 2 & $1-\mathrm{D}$ \\
\hline & & Cold Leg 3 & $1-\mathrm{D}$ \\
\hline & & Reactor Coolant Pump 3 & $1-\mathrm{D}$ \\
\hline & & Cold Leg 4 & $1-\mathrm{D}$ \\
\hline & & Reactor Coolant Pump 4 & $1-\mathrm{D}$ \\
\hline & \multirow[t]{2}{*}{ Hot Leg } & Hot Leg 1 & $1-\mathrm{D}$ \\
\hline & & Hot Leg 2 & $1-\mathrm{D}$ \\
\hline
\end{tabular}


...continued...APEX R7 Model Components.

\begin{tabular}{|c|c|c|c|}
\hline System & Group & Component Name & Dimension \\
\hline \multirow{12}{*}{ 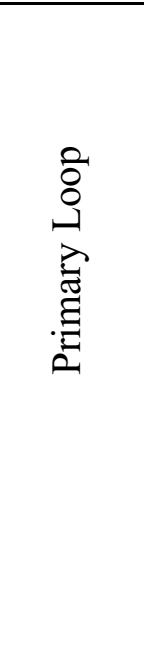 } & Steam Generator & Steam Generator 1 U-Tubes & $1-\mathrm{D}$ \\
\hline & & Steam Generator 1 Primary & $0-\mathrm{D} / 3-\mathrm{D}$ \\
\hline & & Hot Side Lower Plenum & \\
\hline & & Steam Generator 1 Primary & $0-\mathrm{D} / 3-\mathrm{D}$ \\
\hline & & Cold Side Lower Plenum & \\
\hline & & Steam Generator 2 U-Tubes & $1-\mathrm{D}$ \\
\hline & & Steam Generator 2 Primary & $0-\mathrm{D} / 3-\mathrm{D}$ \\
\hline & & Hot Side Lower Plenum & \\
\hline & & Steam Generator 2 Primary & $0-\mathrm{D} / 3-\mathrm{D}$ \\
\hline & & Cold Side Lower Plenum & \\
\hline & Pressurizer & Pressurizer Surge Line & $1-\mathrm{D}$ \\
\hline & & Pressurizer & $0-\mathrm{D}$ \\
\hline \multirow{19}{*}{  } & ADS 1-3 & ADS 1-3 Piping & $1-\mathrm{D}$ \\
\hline & & Oriface (ORI-653) & $1-\mathrm{D}$ \\
\hline & & ADS 1 Valve (RCS-601) & $1-\mathrm{D}$ \\
\hline & & Oriface (ORI-655) & $1-\mathrm{D}$ \\
\hline & & ADS 2 Valve (RCS-602) & $1-\mathrm{D}$ \\
\hline & & Oriface (ORI-656) & $1-\mathrm{D}$ \\
\hline & & ADS 3 Valve (RCS-603) & $1-\mathrm{D}$ \\
\hline & & Oriface (ORI-657) & $1-\mathrm{D}$ \\
\hline & & ADS 1-3 Seperator Tank & $0-\mathrm{D}$ \\
\hline & & Oriface (ORI-659) & $1-\mathrm{D}$ \\
\hline & CVS & CVS Piping & $1-\mathrm{D}$ \\
\hline & & Ball Valve (RCS-820) & $1-\mathrm{D}$ \\
\hline & & Check Valve (RCS-827) & $1-\mathrm{D}$ \\
\hline & & Air Operated Valve (RCS-808) & $1-\mathrm{D}$ \\
\hline & & Check Valve (RCS-809) & $1-\mathrm{D}$ \\
\hline & & CVS Pump & $1-\mathrm{D}$ \\
\hline & PRHR & PRHR Piping & $1-\mathrm{D}$ \\
\hline & & PRHR Oulet Valve (RCS-84) & $1-\mathrm{D}$ \\
\hline & IRWST & IRWST Tank & $0-\mathrm{D}$ \\
\hline
\end{tabular}


Chapter 3

\title{
Primary Loop Inputs
}

\author{
3.1 Core Downcomer
}

3.1.1 R7 Model

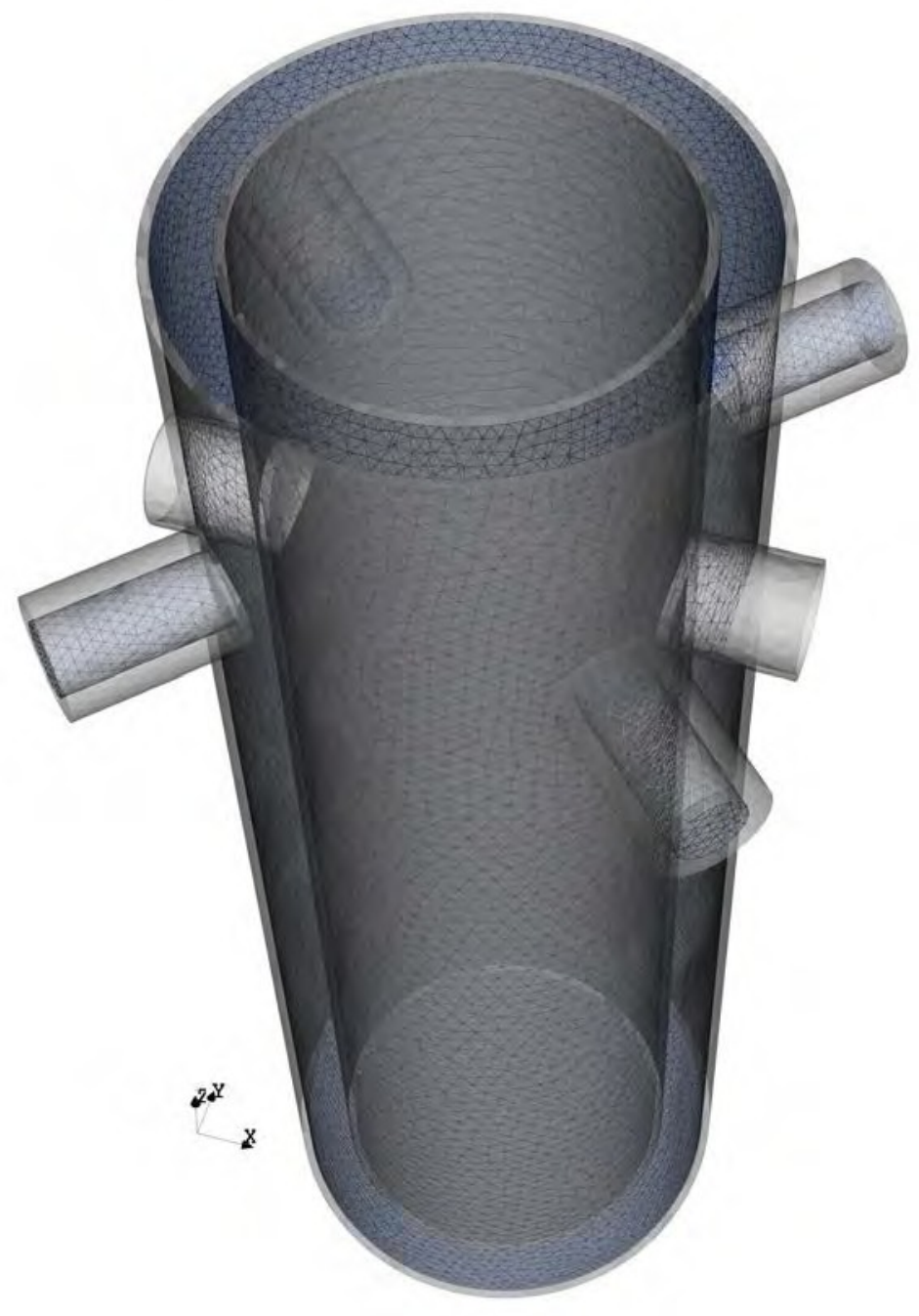

Fig. 3.1 : Core Downcomer. 


\subsection{Core Lower Plenum}

\subsubsection{R7 Model}



Fig. 3.2 : Core Lower Plenum. 


\subsection{1 $R_{7}$ Model}

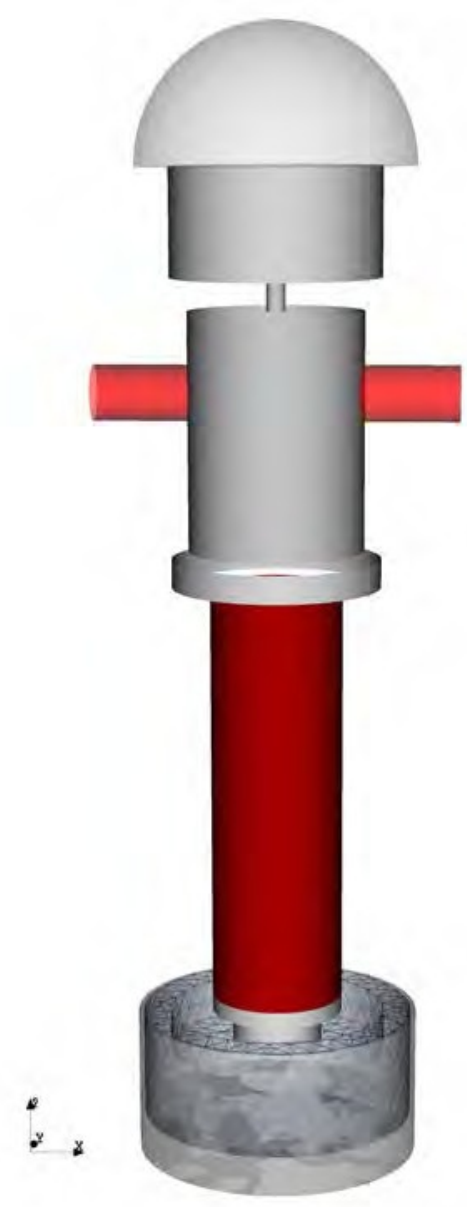

Fig. 3.3 : Core. 


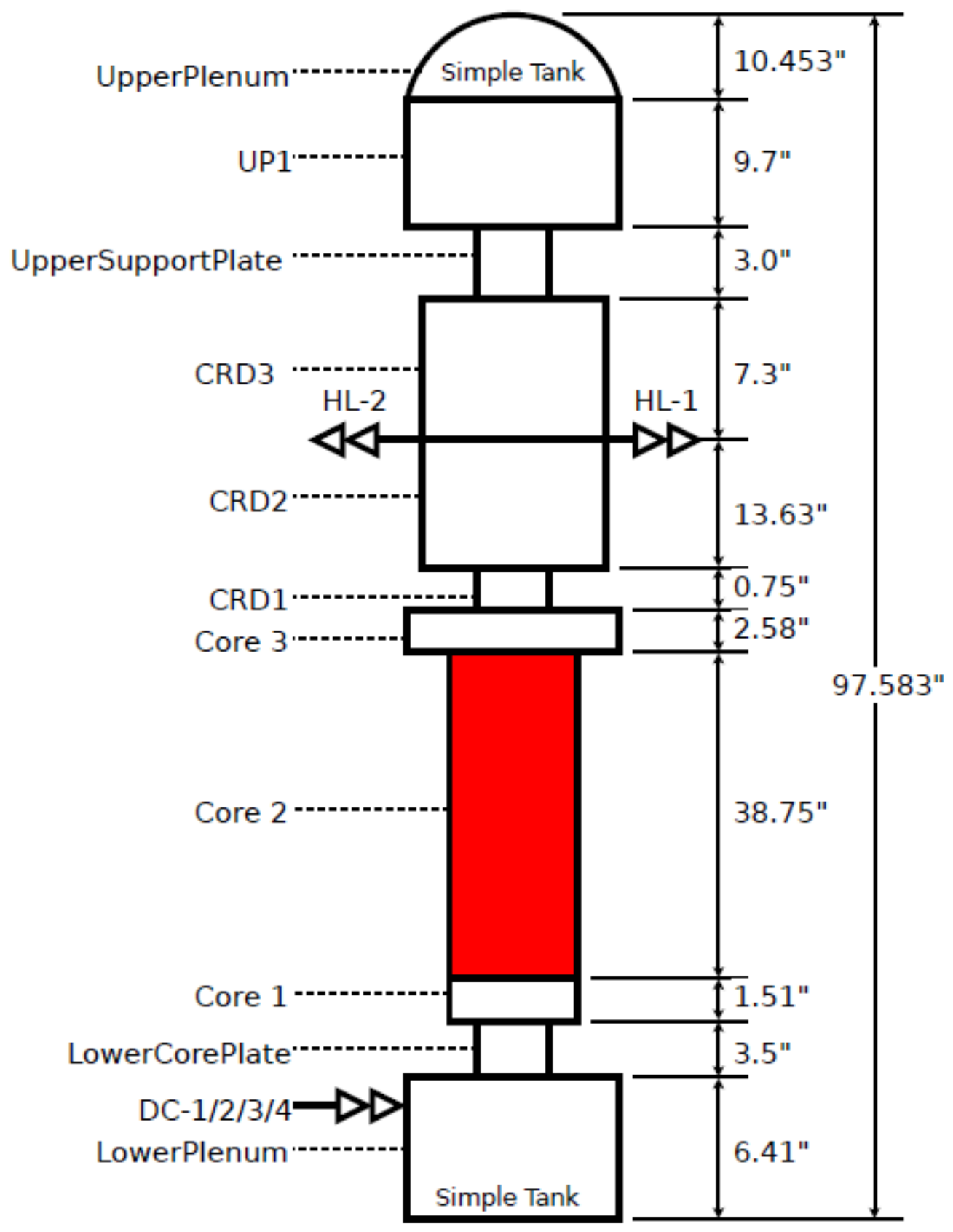

Fig. 3.4: Core. 


\subsection{Core Upper Plenum}

\subsection{1 $\quad R_{7}$ Model}

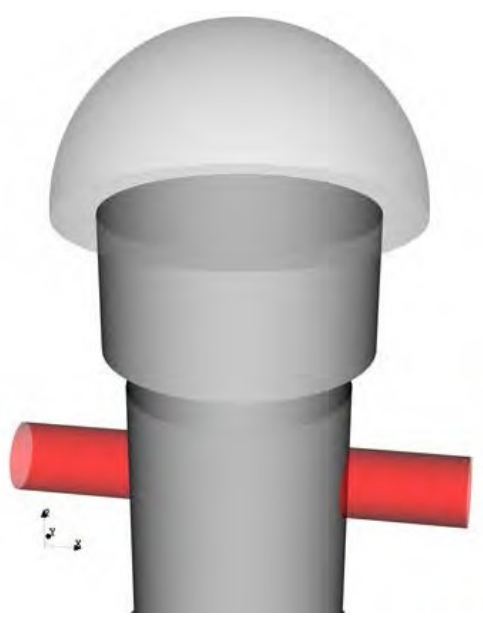

Fig. 3.5 : Core Upper Plenum.

\subsection{Cold Leg 1}

\subsection{1 $\quad R_{7}$ Model}



Fig. 3.6 : Cold Leg 1 . 
3.6 Cold Leg 2

3.6.1 R7 Model



Fig. 3.7 : Cold Leg 2. 
3.7 Cold Leg 3

\subsection{1 $\quad R_{7}$ Model}

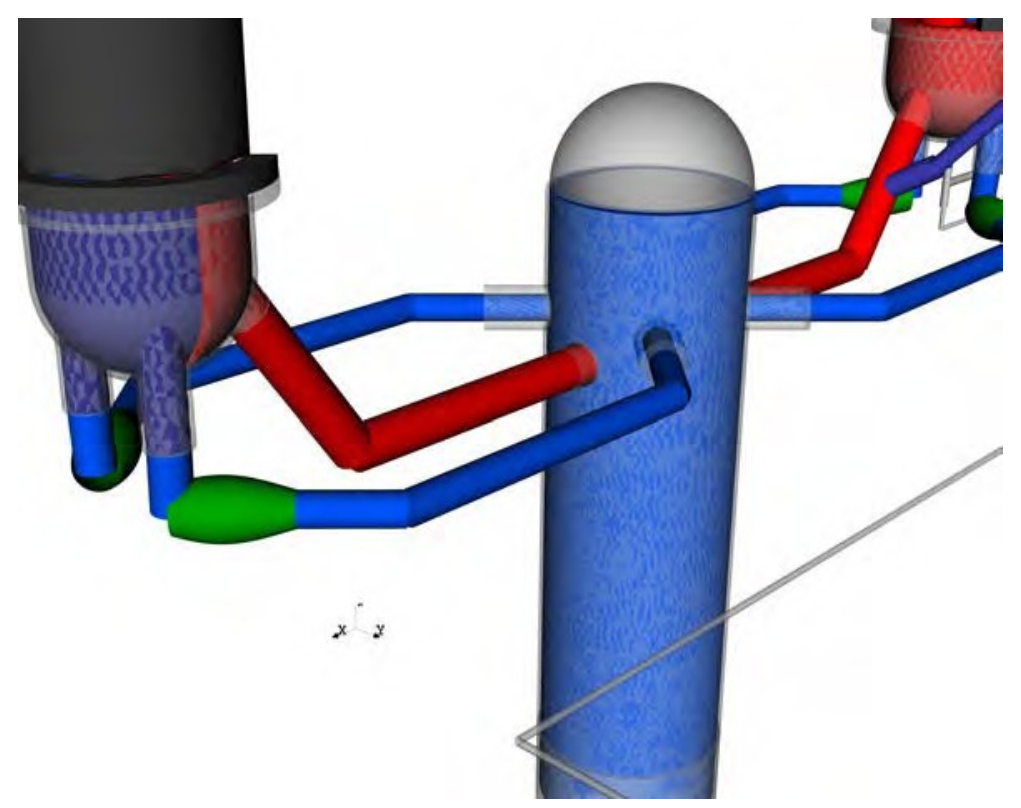

Fig. 3.8 : Cold Leg 3 . 


\subsection{Cold Leg 4}

\subsection{1 $\quad R_{7}$ Model}

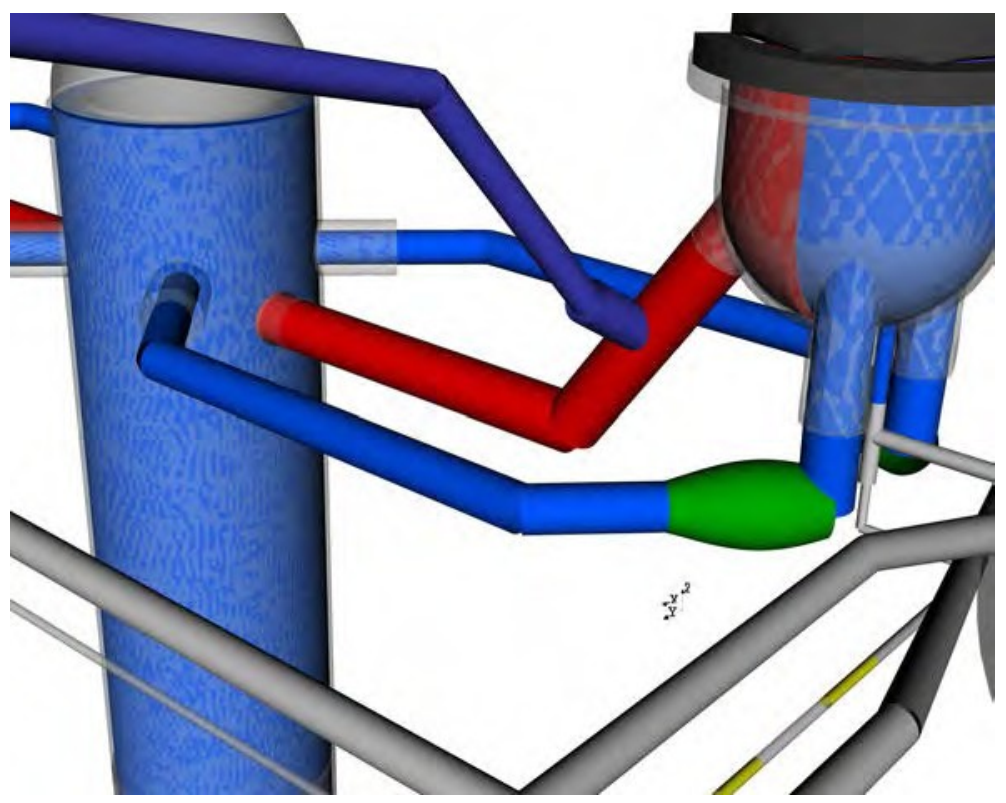

Fig. 3.9 : Cold Leg 4. 
3.9 Hot Leg 1

3.9.1 R7 Model



Fig. 3.10 : Hot Leg 1. 
3.10 Hot Leg 2

3.10.1 R7 Model



Fig. 3.11 : Hot Leg 2. 


\subsection{Steam Generator 1 U-Tubes}

\subsubsection{R7 Model}

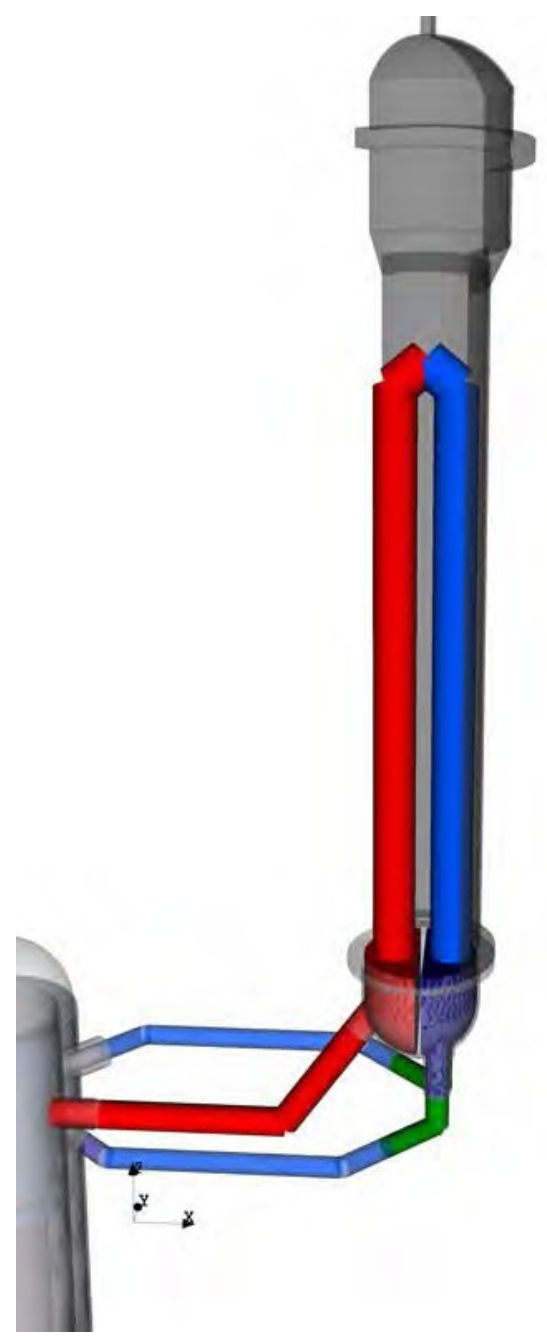

Fig. 3.12 : Steam Generator U-Tubes. 
3.12 Steam Generator 1 Hot Lower Plenum

\subsubsection{R7 Model}

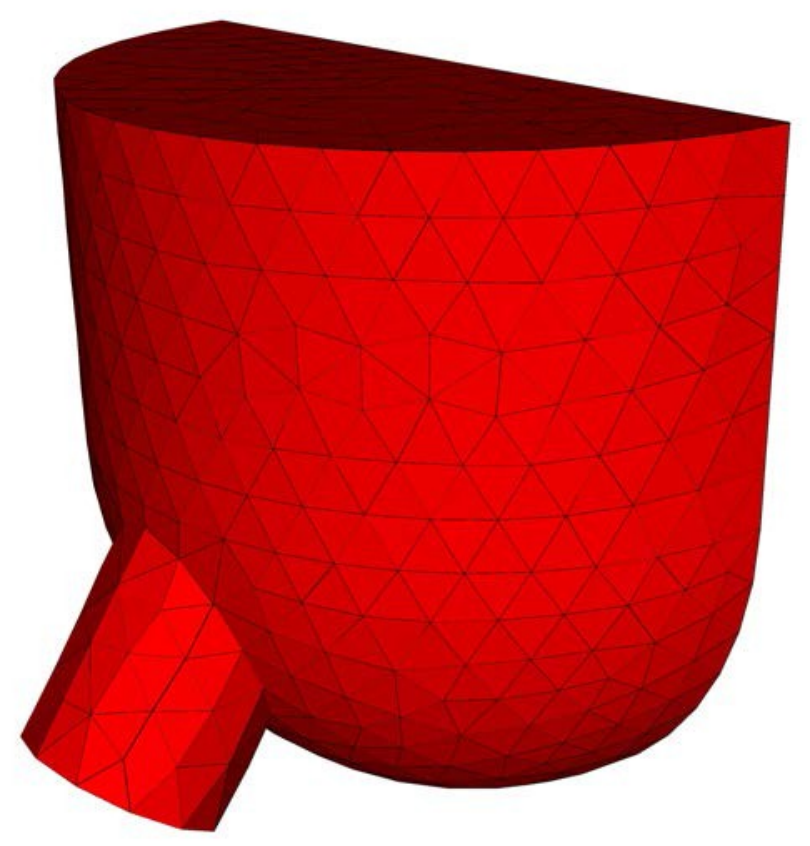

Fig. 3.13 : Steam Generator 1 Hot Lower Plenum. 


\subsection{Steam Generator 1 Cold Lower Plenum}

\subsubsection{R7 Model}

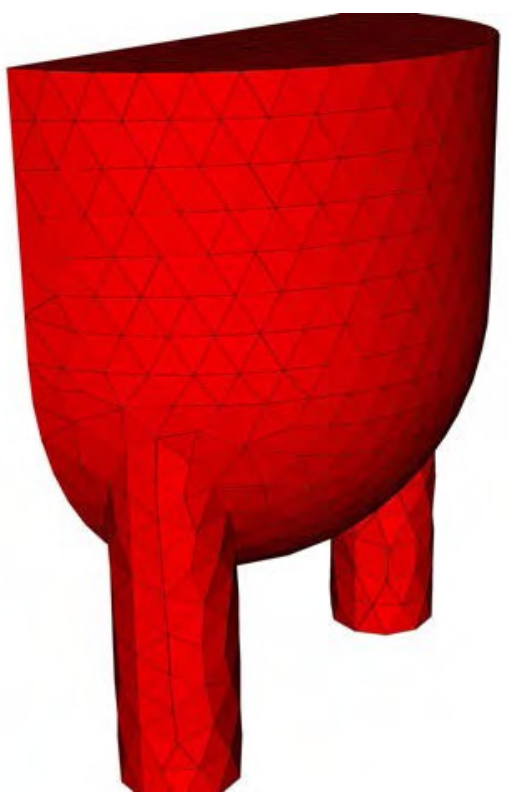

Fig. 3.14 : Steam Generator 1 Cold Lower Plenum. 
3.14 Steam Generator 2 U-Tubes

\subsection{1 $\quad$ R7 Model}



Fig. 3.15 : Steam Generator U-Tubes. 


\subsection{Steam Generator 2 Hot Lower Plenum}

\subsubsection{R7 Model}

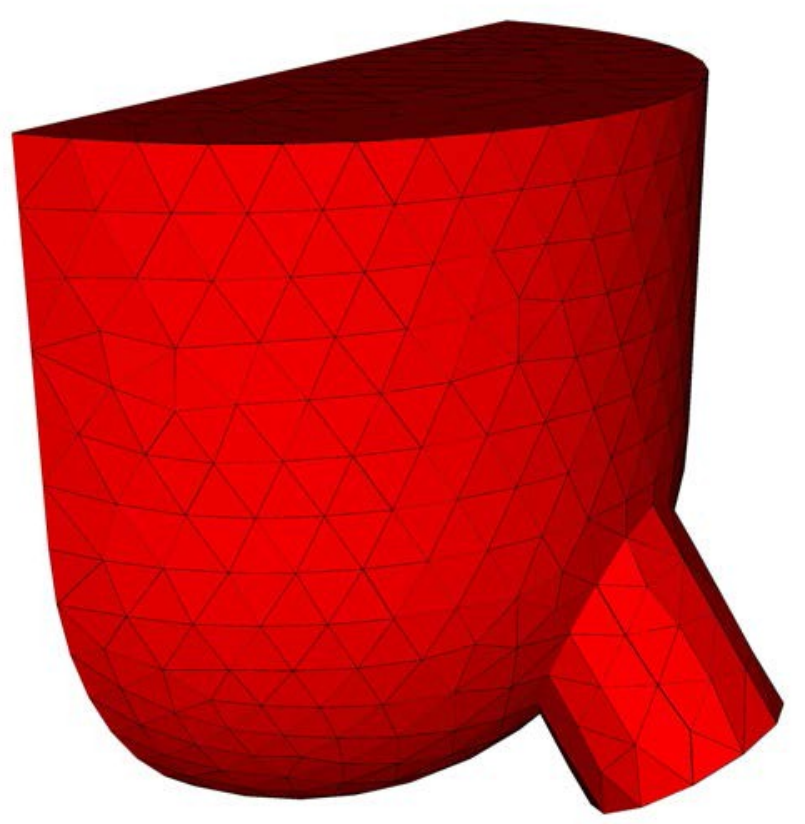

Fig. 3.16 : Steam Generator 2 Hot Lower Plenum. 
3.16 Steam Generator 2 Cold Lower Plenum

3.16.1 R7 Model

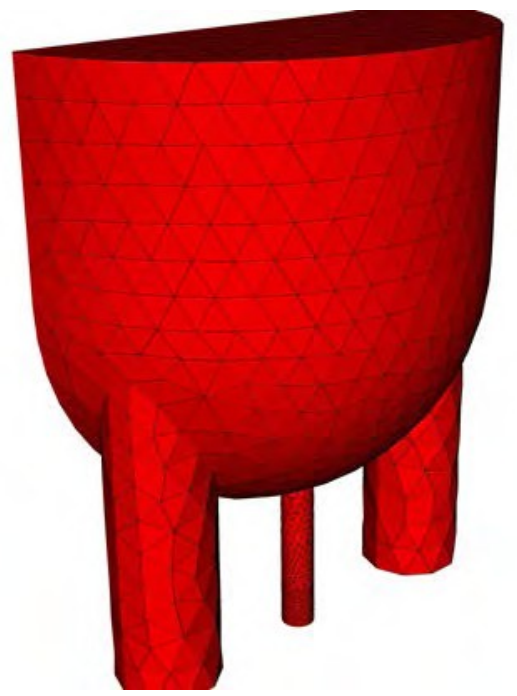

Fig. 3.17 : Steam Generator 2 Cold Lower Plenum. 


\subsection{Pressurizer Surge Line}

\subsubsection{R7 Model}



Fig. 3.18: Pressurizer Surge Line. 
3.18.1 $R_{7}$ Model

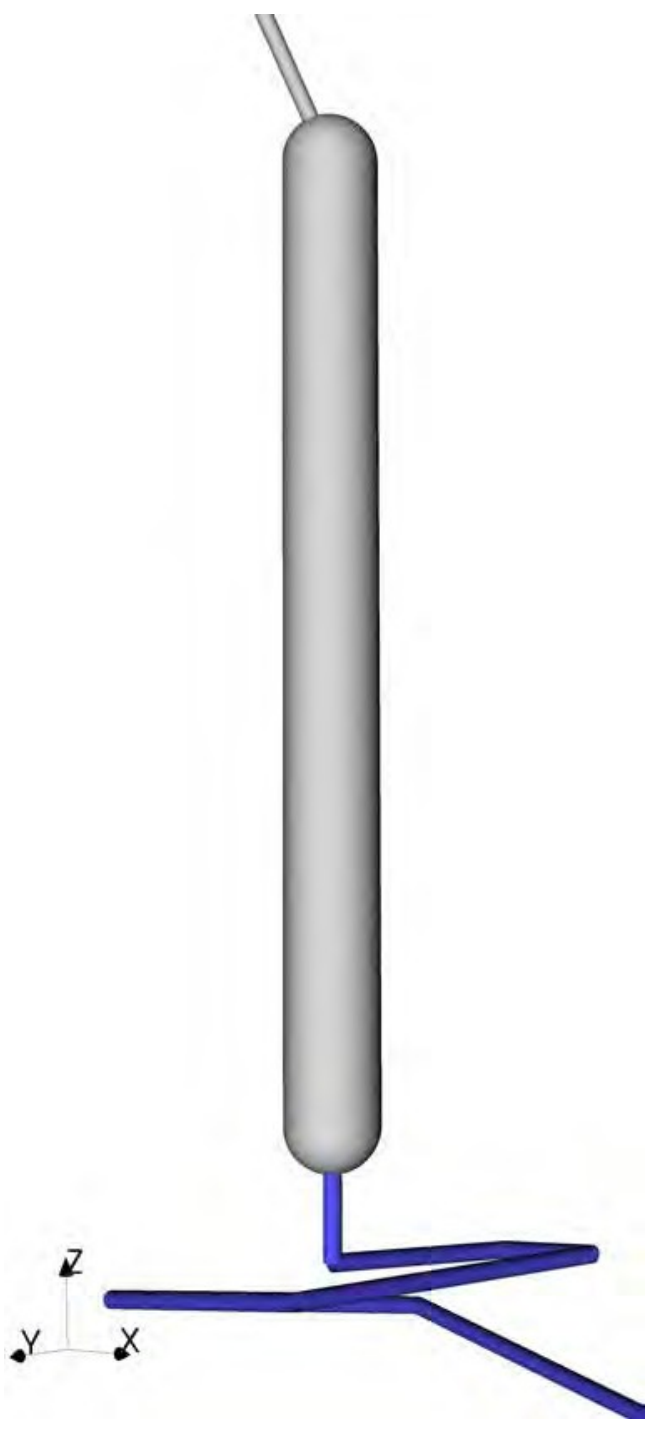


Chapter 4

\section{Safety System Inputs}

\subsection{1 $R_{7}$ Model}

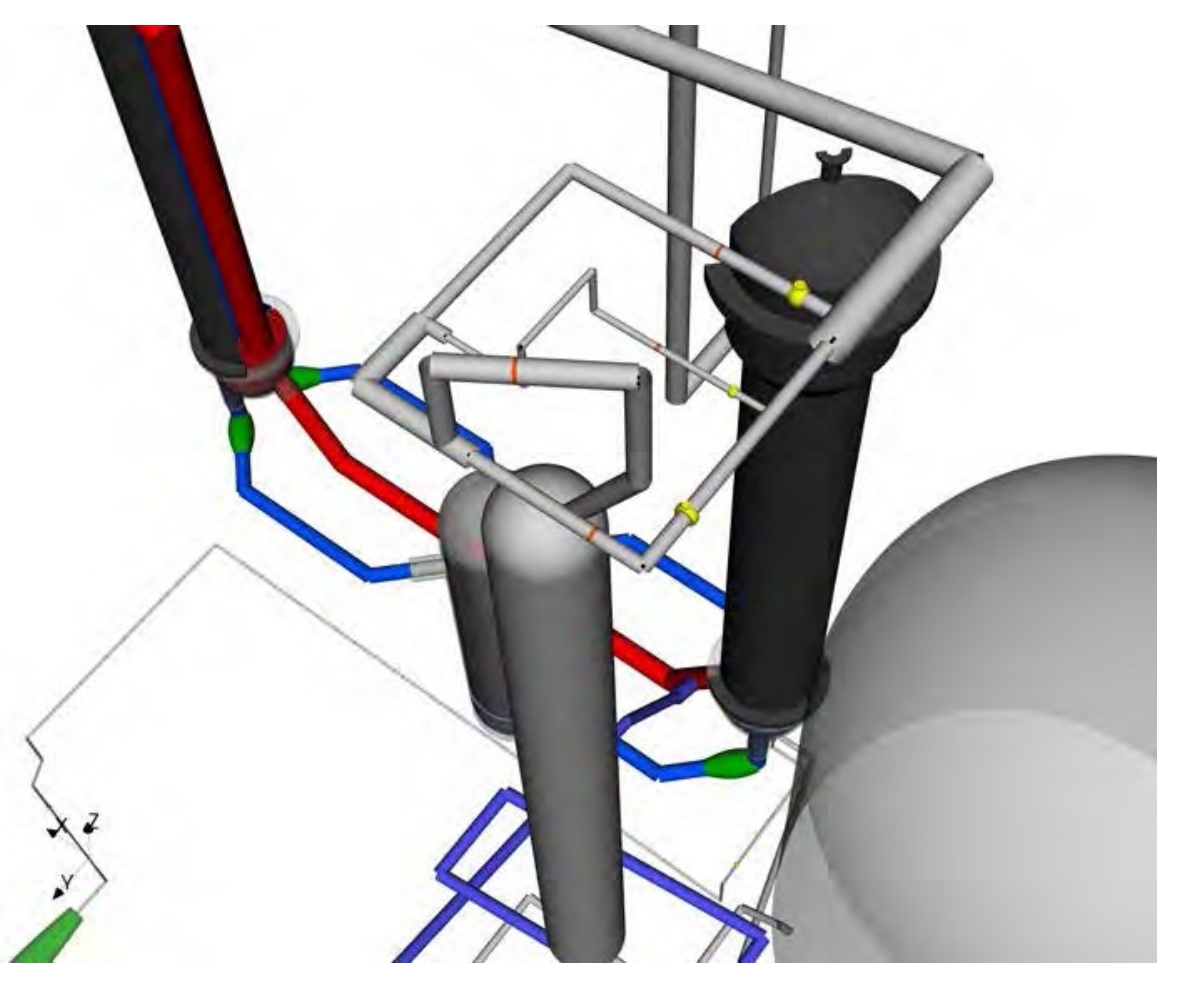

Fig. 4.1 : Automatic Depressurization System 1/2/3 


\section{Reference 2: Owen Stevens, Characterization of the Advanced Plant Experiment (APEX) Passive Residual Heat Removal System Heat Exchanger}

As noted in reference 2 :

"The OSU Radiation Center (the location of the Oregon State University Department of Nuclear Engineering) houses a one quarter scale model of the Westinghouse Electric Corporation advanced lightwater nuclear reactor design called AP600.

The AP-600 reactor design incorporates many passive safety features for reactor core cooling. In this case, passive means that the systems are capable of core cooling using only the phenomena of gravity driven flow and natural convection of heated fluids. The model of the AP-600 (APEX) was built to perform the testing necessary for design certification.

APEX operates at $2.76 \mathrm{MPa}$ (400 Psia) and has been formally scaled' to simulate the important thermal hydraulic behavior of the AP-600. APEX is electrically heated and simulates the nuclear steam supply system (NSSS) and all of the AP-600 safety systems. The systems modeled include the primary system, passive safety systems, the non-safety grade chemical and volume control system, and the residual heat removal system (PRHR).."

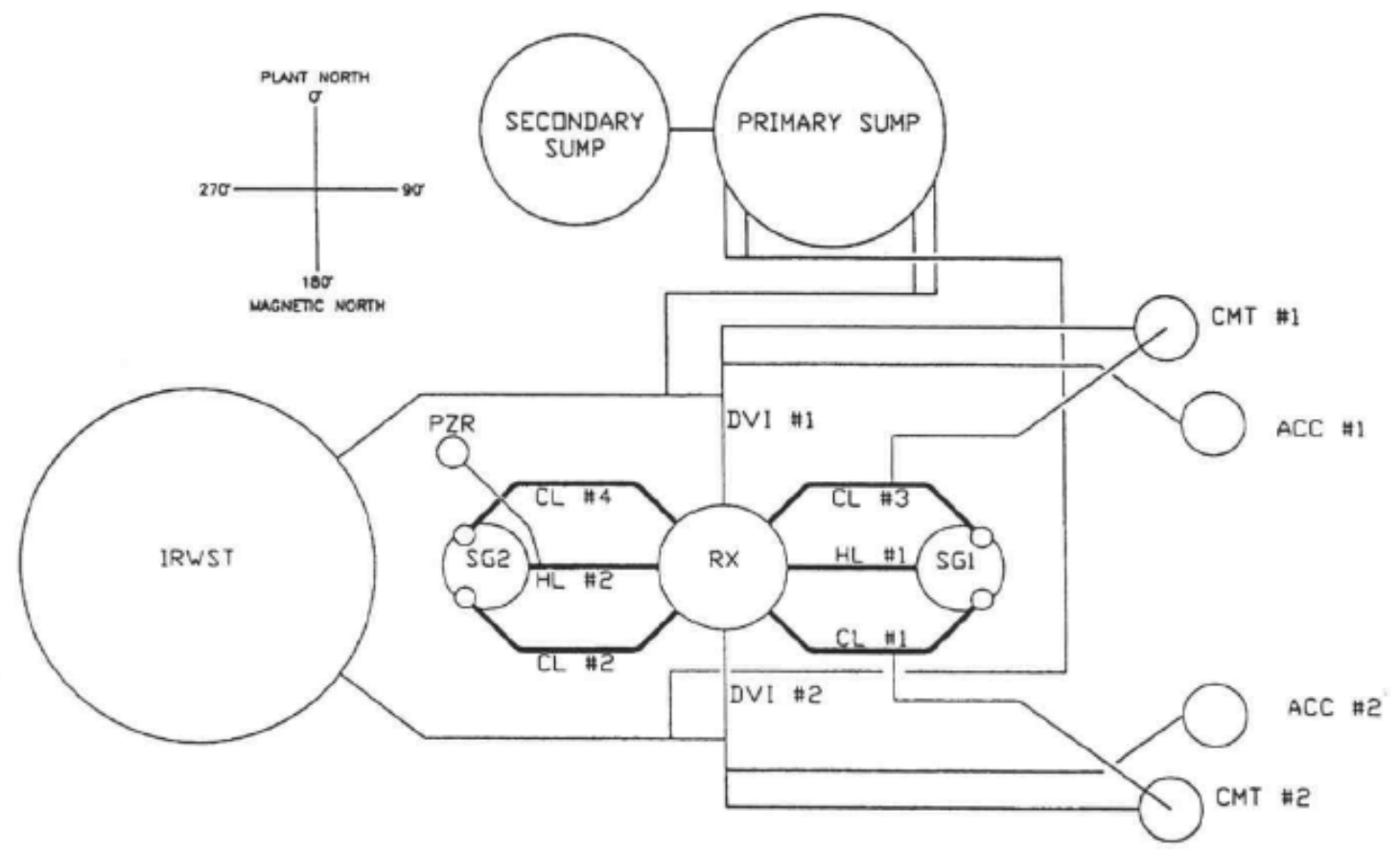

Additional details on the system shown above are found in the Reference 2 report. 
Reference 3: J. Reyes, Jr., Q. Wu, and J. King, Jr., Scaling Assessment for the Design of the OSU APEX-1000 Test Facility, OSU-APEX-03001 (Rev. 0), May 2003.

Reference 3 explains some of the concepts behind the scaling approach used by the APEX researchers. While much of the technical information in Reference 3 has been redacted from the public document, some information is still presented, including:

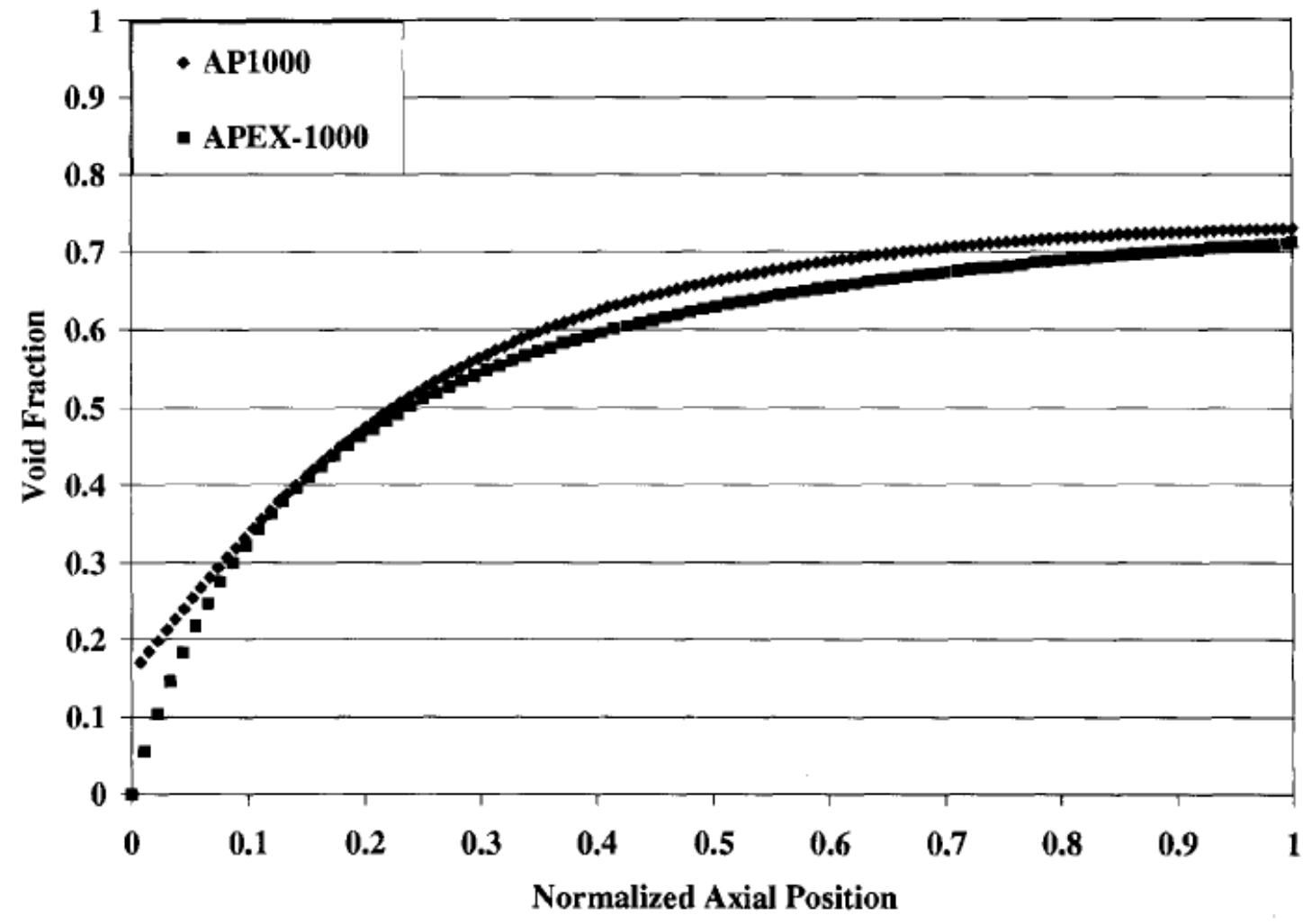

Figure 18 Comparison of AP1000 and APEX Axial Void Fraction Profiles for an Average Subchannel 


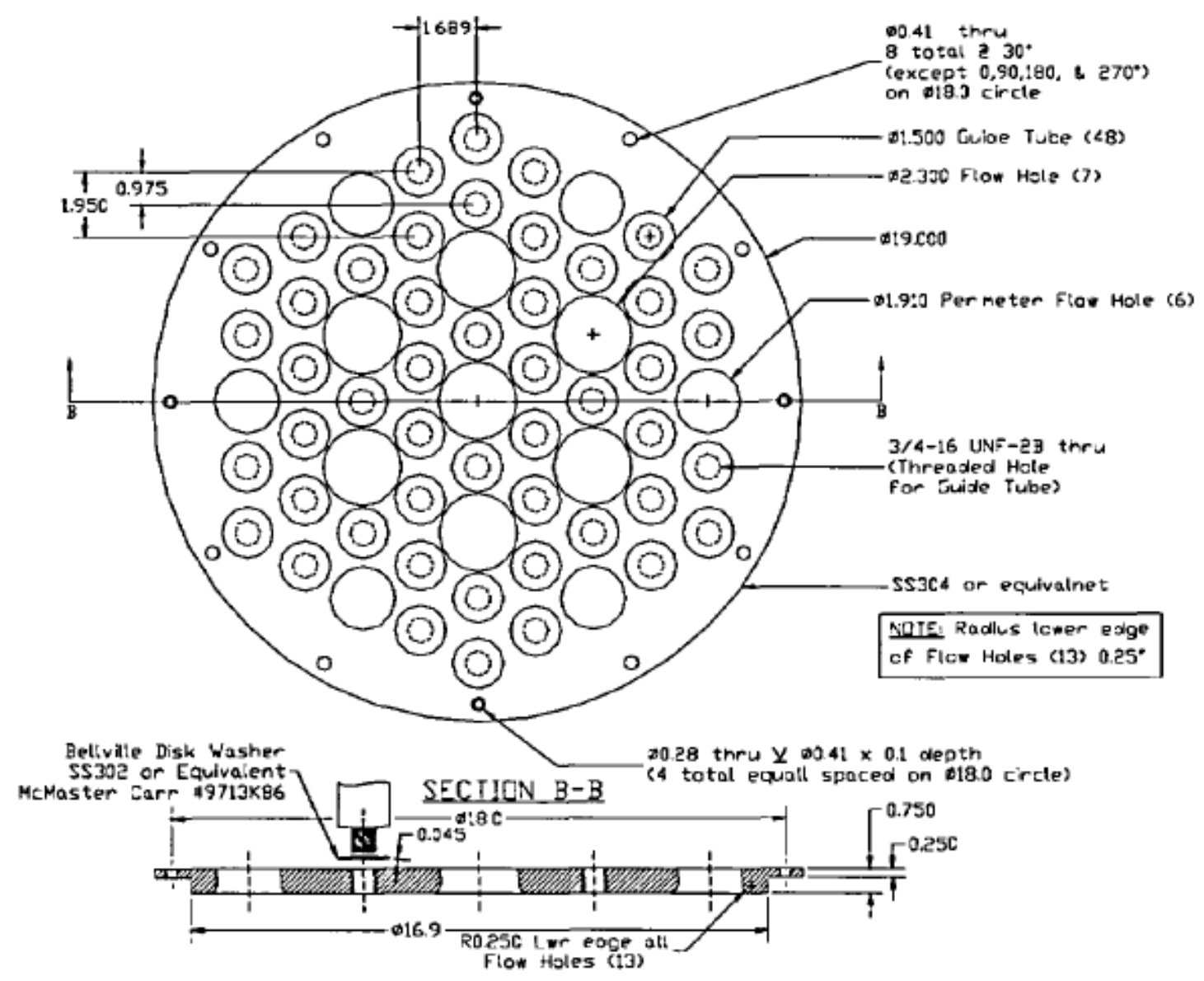

Figure 21 APEX Upper Core Plate Geometry 


\section{Reference 4: J. Reyes et al, Final Report of the NRC AP600 Research Conducted at Oregon State University, NUREG/CR-6641, July 1999.}

Reference 4 summarizes the research effort performed using APEX at Oregon State University. Some facility information is shown in the report, however the report notes:

"Three proprietary compact disks are available as a supplement to this report. They include APEX Facility Drawings, APEX Test Reports, and the APEX Database. These three compact disks include all of the information generated in support of NRC's test program at OSU."

The information from the compact disks is not publically available. Summary of information show in this reference includes:

Layout of the APEX Test Facility

The APEX Testing Facility

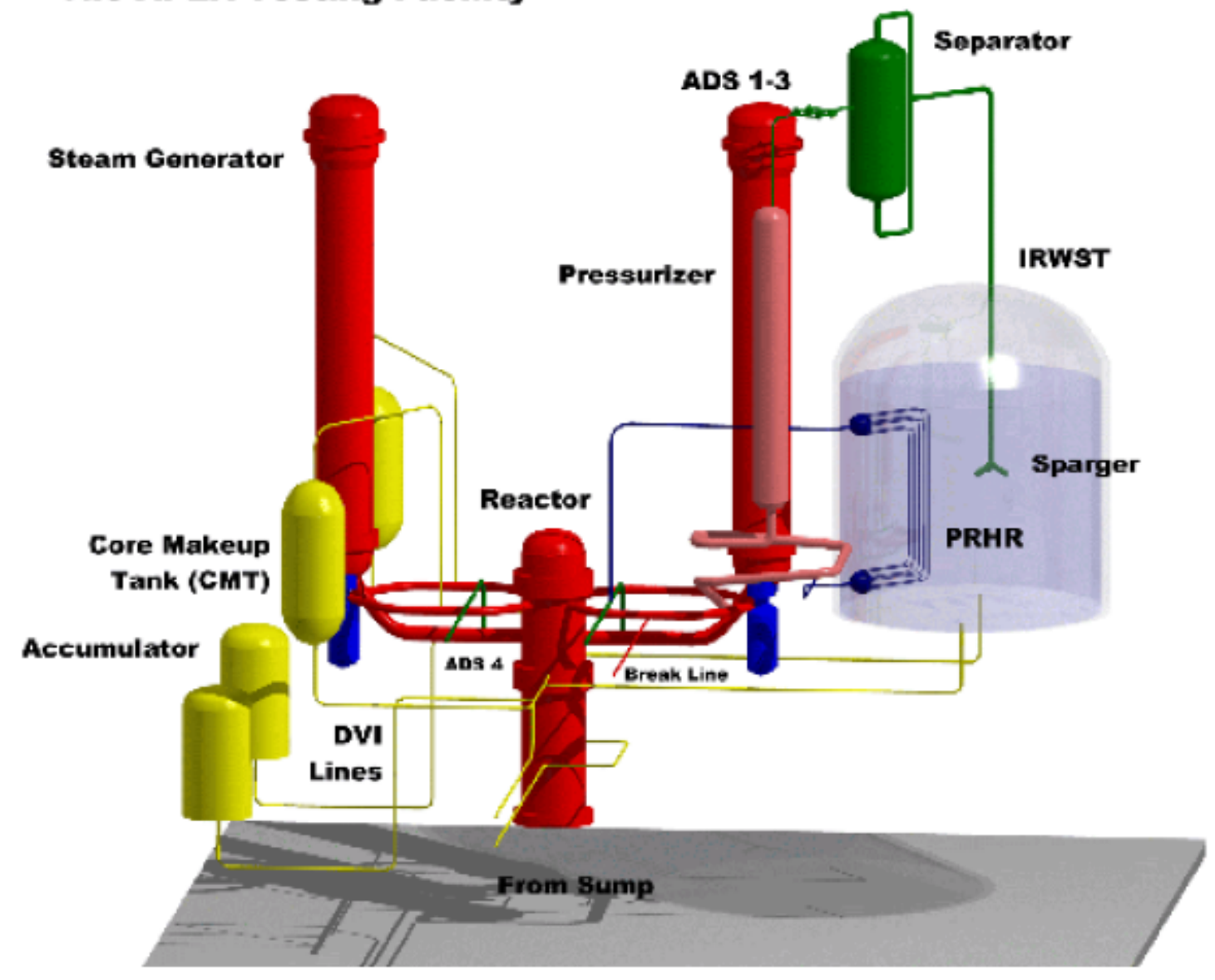

Photos of key parts of the system shown above are included in the report. Information related to the testing initial conditions are also included. 


\section{Reference 5: K. Welter et al, APEX-1000 Confirmatory Testing to Support AP1000 Design}

Certification (non-proprietary), NUREG-1826, August 2005.

This reference describes the NRC-sponsored tests that were run using the APEX facility during the 20032004 time-period. Limited dimensional information is provided. 
